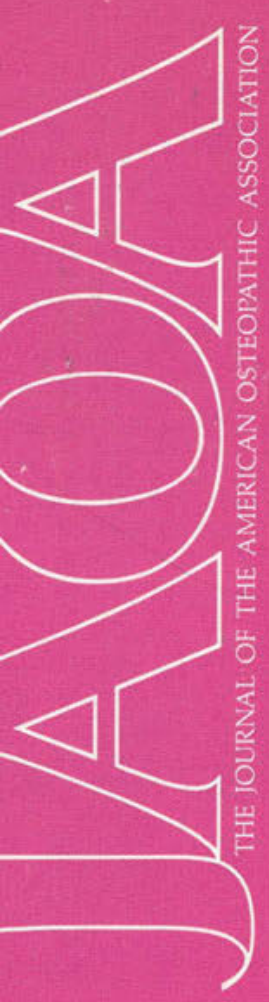

JULY 1989

Chronic cervical dysfunction

Low back pain: Six newly discovered tender points

Cocaine abuse: Unusual medical complications

ADA guidelines for diabetes care
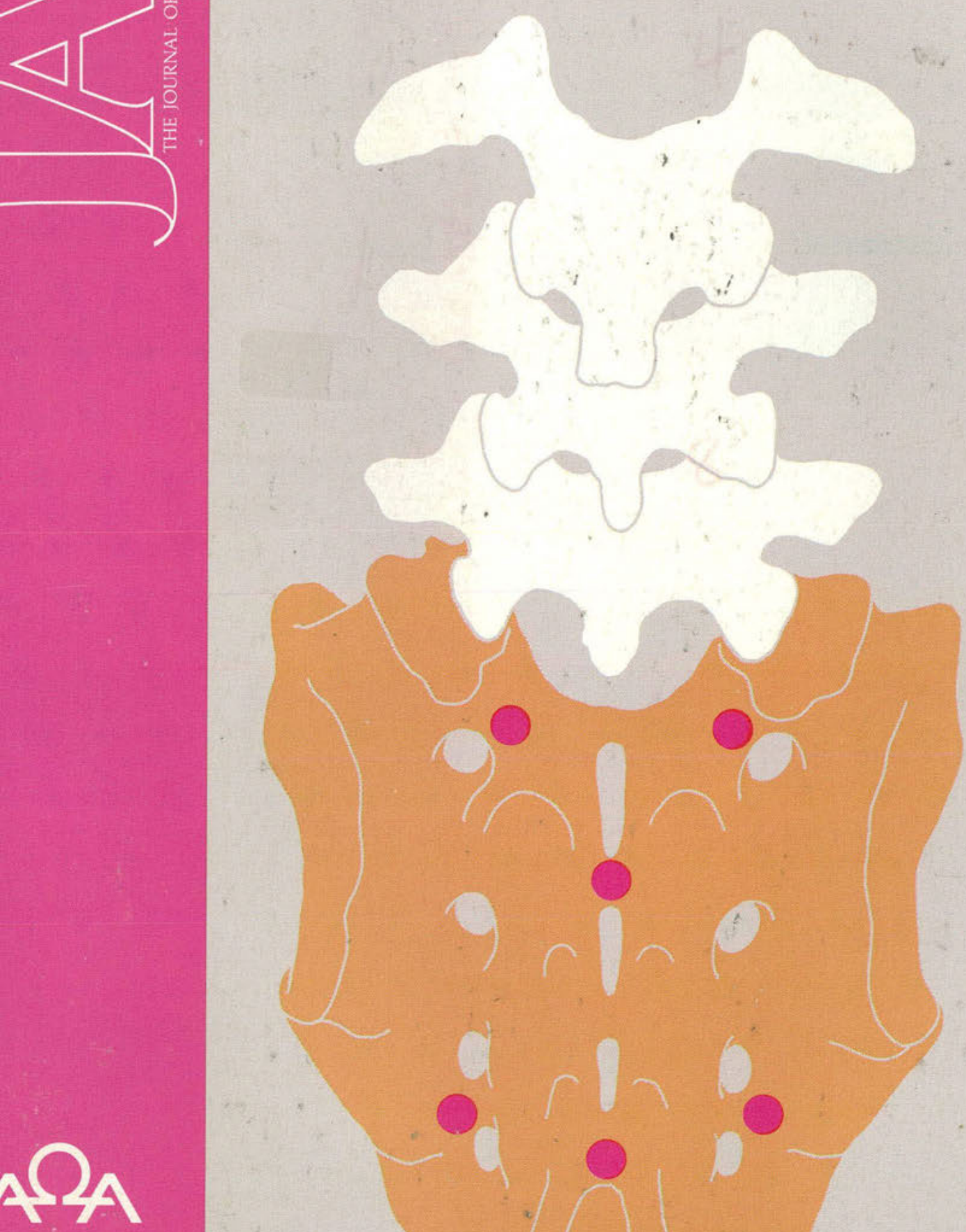
State by state...There's a way

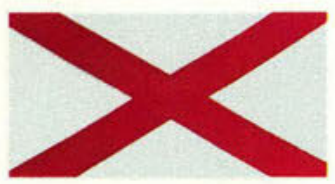

ALABAMA

Sign on the right-

"Dispense as Written" line

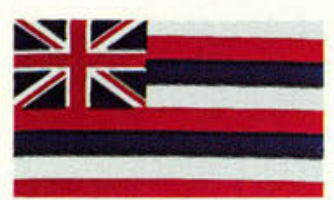

HAWAII

"Do Not Substitute"

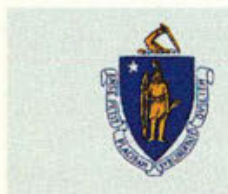

MASSACHUSETTS

"No Substitution"

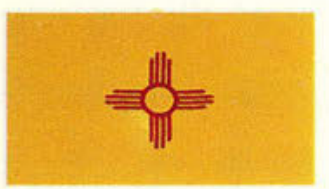

NEW MEXICO

"No Substitution"

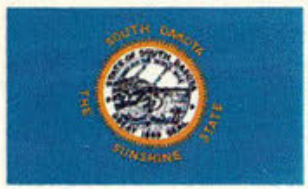

SOUTH DAKOTA

Sign on the right-

"Dispense as Written" line

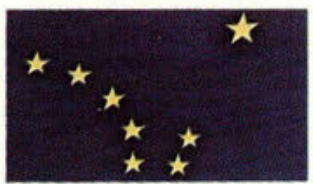

ALASKA

"Dispense as Written"

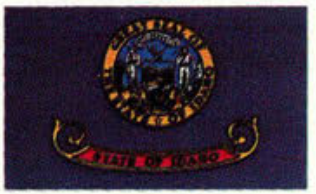

IDAHO

Sign on the right

"Dispense as Written" line

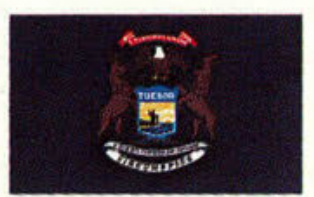

MICHIGAN

"Dispense as Written"

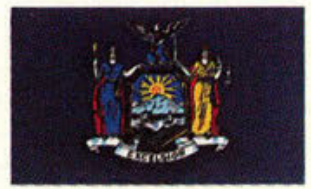

NEW YORK

Write "D.A.W." in box

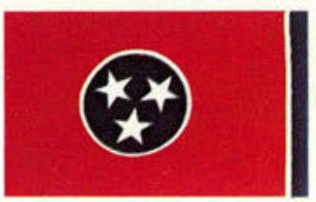

TENNESSEE

Sign on the

"Dispense as Written" line

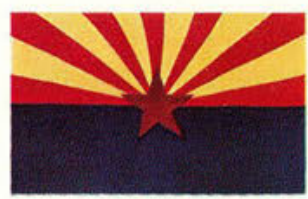

ARIZONA

Sign on the left-

"Dispense as Written" line

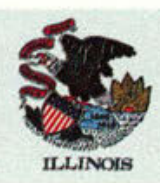

ILLINOIS

Check box-

"May Not Substitute'

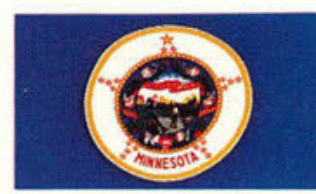

MINNESOTA

"Dispense as Written"

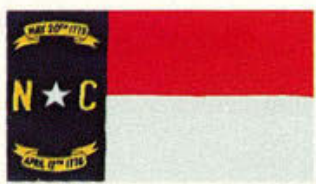

NORTH CAROLINA

Sign on the right-

"Dispense as Written" line

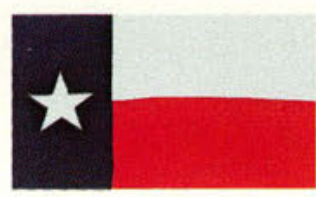

TEXAS

Sign on the right"Dispense as Written" line

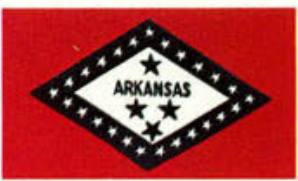

ARKANSAS

Write "Dispense as Written" and initial

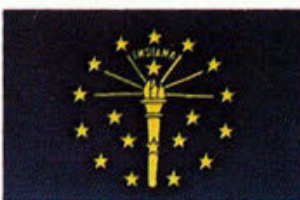

INDIANA

Sign on the left-

"Dispense as Written" line

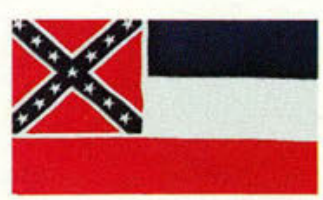

MISSISSIPPI

"Dispense as Written"

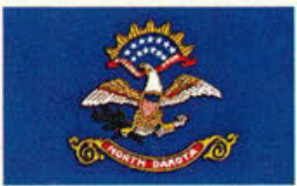

NORTH DAKOTA

Sign on the right-

"Dispense as Written" line

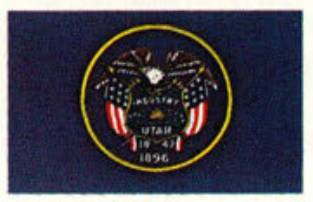

UTAH

“Dispense as Written'

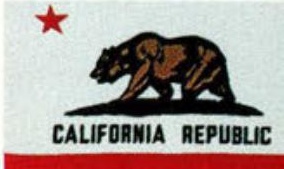

CALIFORNIA

"Do Not Substitute"

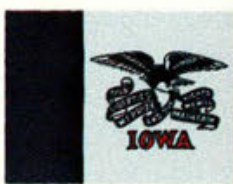

IOWA

"No Substitution"

or "D.A.W."

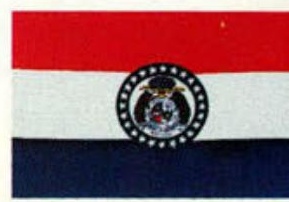

MISSOURI

Sign on the right"Dispense as Written" line

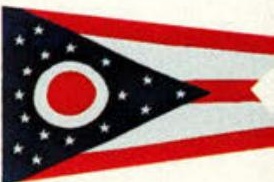

$\mathrm{OHIO}$

"Dispense as Written"

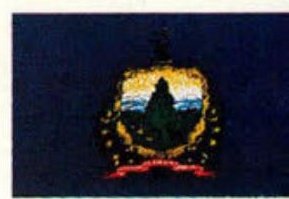

VERMONT

"No Substitution"

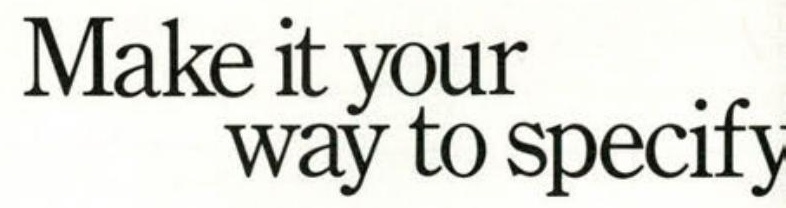

\section{ROCHE Roche Products}




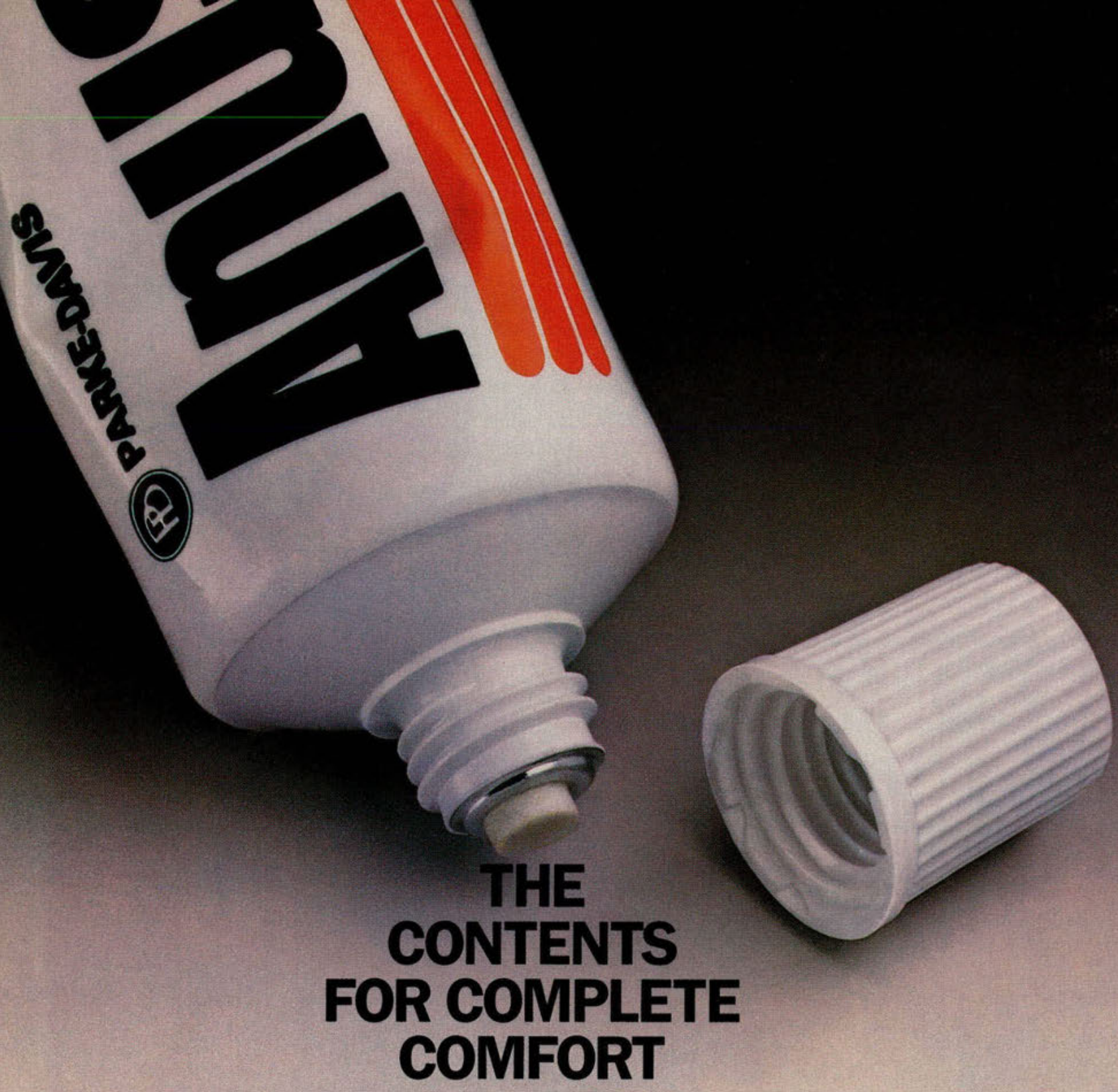

ANUSOL ${ }^{\otimes}$ Ointment and Suppositories offer just the right active ingredients to relieve discomfort from hemorrhoids and irritated anorectal tissue. Zinc oxide,

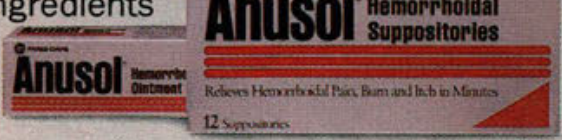

but less sensitizing. Used on sensitive perianal surfaces, pramoxine $\mathrm{HCl}$ provides prompt pain relief.

ANUSOL Ointment and available in both formulations, soothes and lubricates tender anorectal tissue, protecting it against further irritation.

ANUSOL Ointment offers the added benefit of pramoxine hydrochloride-an effective local anesthetic that's as potent as benzocaine

Suppositories...formulated to deliver complete comfort.

To receive a complimentary supply of patient booklets on relieving anorectal discomfort, along with an easel display, call 1-800-537-5179.

\section{Anusol}

Hemorrhoidal Suppositories and Ointment

\section{All the ingredients for soothing hemorrhoidal relief}

